\title{
PEMBELAJARAN TERINTEGRASI STEM UNTUK MENINGKATKAN LITERASI MATEMATIS MAHASISWA CALON GURU MATEMATIKA PADA PERKULIAHAN PRA-KALKULUS 1
}

\author{
Sulistiawati ${ }^{1}$, Dadang Juandi ${ }^{2}$, Ricky Yuliardi ${ }^{3}$ \\ 1,2,3 Universitas Pendidikan Indonesia, Jl. Dr. Setiabudi No. 229, Bandung, Indonesia \\ ${ }^{1}$ STKIP Surya Tangerang, Jl. Boulevard Gading Serpong, Banten, Indonesia \\ ${ }^{3}$ STKIP Muhammadiyah Kuningan, Jl. Syeh Maulana Akbar, Kuningan, Indonesia \\ Email: ${ }^{1}$ sulistiawati@upi.edu, ${ }^{1}$ sulistiawati@stkipsurya.ac.id
}

\begin{abstract}
This research is motivated by the low of mathematical literacy as a global concern in mathematics learning/lectures. One way to grow mathematical literacy is to integrate STEM (Science, Technology, Engineering, and Mathematics) into learning. The purpose of this study are: (1) to describe learning that integrates STEM into Pre-Calculus 1 lectures for prospective mathematics teachers in function materials; (2) to describe how to improve the mathematical literacy skills of prospective mathematics teachers through STEM-integrated learning; and (3) to describe how prospective mathematics teachers respond to STEM-integrated learning. The method in this study is descriptive research with quantitative and qualitative approaches. The subject of this study are six students of STKIP Surya Tangerang who participated in pre-calculus 1 lecture in the Odd Semester of academic year 2019/2020. The instruments in this study are mathematical literacy tests (7 question items) and questionnaires ( 30 statement items). The results of this study are: (1) Pre-Calculus 1 lecture with STEM-integrated learning in function materials for prospective mathematics teachers delivered by conveying concepts starting from context and also their implementation in the fields of science, technology, engineering, and mathematics through the learning process in lectures, demonstrations, explorations, exercises, and project assignments; (2) students have mastery of mathematical literacy with an increase in the moderate category; and (3) students respond positively to STEM-integrated learning to improve mathematical literacy.
\end{abstract}

Keywords: Function materials, math literacy, pre-calculus, STEM-integrated learning

\begin{abstract}
ABSTRAK
Penelitian ini dilatarbelakangi oleh masih rendahnya literasi matematis yang menjadi perhatian global dalam pembelajaran/perkuliahan matematika. Salah satu cara untuk menumbuhkan literasi matematis adalah dengan mengintegrasikan STEM (Science, Technology, Engineering, and Mathematics) dalam pembelajaran. Tujuan penelitian ini adalah untuk: (1) mendeskripsikan pembelajaran yang mengintegrasikan STEM pada perkuliahan Pra Kalkulus 1 bagi mahasiswa calon guru matematika pada materi fungsi; (2) mendeskripsikan bagaimana peningkatan literasi matematis mahasiswa calon guru matematika melalui pembelajaran yang terintegrasi STEM; dan (3) mendeskripsikan bagaimana respon mahasiswa calon guru matematika terhadap pembelajaran yang terintegrasi STEM. Metode dalam penelitian ini adalah penelitian deskriptif dengan pendekatan kuantitatif dan kualitatif. Subjek penelitian ini adalah 6 mahasiswa calon guru matematika di STKIP Surya yang mengikuti pembelajaran/perkuliahan Pra-Kalkulus 1 pada Semester Ganji Tahun Akademik 2019/2020. Instrumen dalam penelitian ini adalah tes literasi matematis (7 butir soal) dan angket (30 butir pernyataan). Hasil penelitian ini adalah: (1) pembelajaran Pra Kalkulus 1 pada materi fungsi terintegrasi STEM bagi mahasiswa calon guru disampaikan dengan menyampaikan konsep-konsep diawali dari konteks dan juga implementasinya dalam bidang sains, teknologi, rekayasa/teknik, dan matematika melalui proses pembelajaran secara ceramah, demonstrasi, eksplorasi, latihan, dan penugasan proyek; (2) mahasiswa memiliki penguasaan literasi matematis dengan peningkatan pada kategori sedang; dan (3) mahasiswa memberikan respon positif terhadap pembelajaran terintegrasi STEM untuk meningkatkan literasi matematis.
\end{abstract}

Kata kunci: Literasi matematis, pembelajaran terintegrasi STEM, pra-kalkulus, materi fungsi

Dikirim: 1 Januari 2021; Diterima: 31 Januari 2021; Dipublikasikan: 30 Maret 2021

Cara sitasi: Sulistiawati, Juandi, D., \& Yuliardi, R. (2021). Pembelajaran terintegrasi stem untuk meningkatkan literasi matematis mahasiswa calon guru matematika pada perkuliahan pra-kalkulus 1. Teorema: Teori dan Riset Matematika, $6(1), 82-97$.

Doi: http://dx.doi.org/10.25157/teorema.v6i1.4727 


\section{PENDAHULUAN}

Beberapa kesulitan belajar bagi mahasiswa pada perkuliahan Logika dan Himpunan masih menjadi isu penting bagi dosen di berbagai Prodi Pendidikan Matematika. Misalkan kesulitan mahasiswa dalam pembuktian matematis pada perkuliahan Logika dan Himpunan, mahasiswa sudah bisa memahami masalah namum belum bisa mentransformasikan dan melakukan pengkodean masalah (Harisman et al., 2020). Selain kemampuan yang bersifat kognitif, sikap mahasiswa dalam belajar juga belum memiliki kemandirian yang baik. Kemandirian belajar mahasiswa rendah karena masih bergantung pada instruksi dosen dalam belajar (Kusuma, 2020). Tidak hanya itu, kesulitan lain mahasiswa adalah kesulitan dalam merumuskan, menafsirkan, dan menggunakan konsep matematika yang mereka miliki untuk memecahkan masalah (Yustitia \& Juniarso, 2019).

Masalah terkait literasi matematis secara umum dapat dilihat dari hasil tes PISA. Sejak tahun 2000, rata-rata prestasi siswa tingkat menengah pertama khususnya dalam matematika selalu berada di bawah rata-rata total dan di luar simpangan baku. Prestasi siswa Indonesia selalu berada di bawah sejak tahun 2000 hingga 2015 (Ahmad et al., 2018). Pada siswa tingkat menengah atas ditemukan bahwa literasi matematis siswa tergolong dalam kategori sangat rendah, dengan rincian untuk indikator pemahaman tergolong rendah, sedangkan untuk indikator membuat model matematika, menggunakan konsep-fakta-objek, menginterpretasi dan mengevaluasi berada pada kategori sangat rendah (Sari \& Wijaya, 2017). Selain tingkat menengah, pada tingkat orang dewasa literasi matematis juga masih menjadi masalah. Dalam penelitian yang dilakukan oleh Ehmke et al. (2005) yang membandingkan literasi matematis orang dewasa dan siswa usia untuk PISA, diperoleh hasil bahwa rata-rata kompetensi literasi matematis orang dewasa sama dengan anak usia 15 tahun.

Assessment and Analytical Framework dalam PISA 2018 (OECD, 2019) menjelaskan bahwa literasi matematis sebagaimana dinilai dan kompetensi yang disyaratkan menjelaskan tentang proses, pengetahuan konten, dan konteks yang tercermin dalam tugas-tugas yang digunakan PISA untuk mengukur literasi sains dan bagaimana kinerja siswa dalam matematika yang diukur dan dilaporkan. Literasi matematis berfokus pada pengukuran kapasitas siswa untuk merumuskan situasi secara matematis (formulating situations mathematically), memanfaatkan konsep, fakta, prosedur, dan penalaran matematis (employing mathematical concepts, facts, procedures and reasoning), dan menafsirkan, menggunakan, dan mengevaluasi hasil matematika (interpreting, applying and evaluating mathematical concepts) dalam konteks yang berbeda (Yildirim \& Sidekli, 2018).

Association of America Colleges and Universities (AAC\&U) merinci literasi matematis ke dalam enam indikator, yaitu: (1) interpretasi; (2) representasi; (3) kalkulasi; (4) asumsi; (5) aplikasi/analisis; dan (6) komunikasi (Rafianti et al., 2018). Penelitian tentang literasi matematis ini menjadi penting untuk dilakukan, karena literasi matematis menjadi salah satu bagian pengukuran dari asesmen yang dilakukan oleh studi PISA (Programme for International Student Assessment) yang diselenggarakan oleh OECD. Urgensi ini juga didasarkan pada kebijakan pemerintah yang telah mencanangkan program Asesmen Kompetensi Minimum (AKM) dan survei karakter bagi siswa-siswa sekolah sebagai pengganti Ujian Nasional (UN) sejak tahun 2020 dan akan dimulai pada tahun 2021 ini (kemdikbud.go.id). Dalam AKM tersebut yang akan menjadi fokus penilaian adalah literasi dan numerasi. Literasi berkaitan dengan kemampuan memahami dan menganalisis bacaan, sedangkan numerasi berkaitan dengan kemampuan menggunakan dan menganalisis angka. Jika dikaitkan dengan studi PISA, numerasi disini dapat diidentifikasi sebagai literasi matematis.

Beberapa penelitian yang berkaitan dengan literasi matematis, diantaranya dilakukan Bolstad (2020) meneliti operasionalisasi literasi matematis guru di Norwegia, menunjukkan hasil bahwa guru masih kesulitan dalam melaksanakan pembelajaran untuk mengembangkan literasi matematis tersebut. Operasionalisasi literasi matematis guru tampaknya terfragmentasi (terpisah-pisah) dan pengajaran difokuskan pada pengembangan kelancaran prosedural. Genc \& Erbas (2019) melakukan penelitian untuk menyelidiki bagaimana konsep literasi matematis guru matematika sekolah menengah. Hasil yang diperoleh bahwa konsepsi guru tentang literasi matematis dikategorikan ke dalam tujuh kelompok, yaitu: memiliki pengetahuan dan keterampilan matematika, matematika 
fungsional, pemecahan masalah, berpikir matematis, penalaran, dan argumentasi, kemampuan matematika bawaan, konseptual pemahaman, dan motivasi belajar matematika.

Upaya untuk memunculkan literasi matematis pada anak (pembelajar) diperlukan strategi pembelajaran yang relevan. Salah satunya dengan pembelajaran STEM, karena pembelajaran tersebut menuntut siswa akrab, melek, dan mahir dengan pengetahuan yang berkaitan dengan sains, teknologi, rekayasa, dan matematika. Harapannya anak akan terbiasa dengan persoalan matematika yang berguna dalam berbagai disiplin ilmu, khususnya sains, teknologi, rekayasa, dan matematika itu sendiri.

Pembelajaran dengan STEM dapat dijadikan sebagai strategi dalam memunculkan literasi matematis peserta didik. Literasi matematis sendiri merupakan salah satu kemampuan yang harus dimiliki peserta didik pada abad 21 ini, di samping keterampilan dalam teknologi (Yildirim \& Sidekli, 2018). Seseorang dikatakan melek (literate) matematis artinya dia tidak sekedar paham tentang matematika akan tetapi juga mampu menggunakannya dalam pemecahan masalah sehari-hari (Masjaya \& Wardono, 2018). Pemecahan masalah sehari-hari dapat dilatih dengan pembelajaran yang mengintegrasikan STEM. Dengan tercapainya hal tersebut, dapat menandakan bahwa salah satu kemampuan matematika yaitu literasi matematis sudah dimiliki siswa.

Selain literasi matematis, penelitian ini memberikan perhatian pada STEM (science, technology, engineering, and mathematics) atau dalam Bahasa Indonesia dikenal dengan sains, teknologi, teknik/rekayasa, dan matematika. STEM telah menjadi isu yang banyak dibicarakan dalam dunia pendidikan dalam satu dekade terakhir. STEM menjadi perhatian, salah satunya berasal dari pidato presiden Amerika Serikat Barack Obama bahwa salah satu fokus presiden pada saat itu adalah membuat pendekatan serba bisa untuk bidang sains, teknologi, rekayasa/teknik, dan matematika (Handelsman \& Smith, 2016). Di kawasan Asia Tenggara, STEM menjadi salah satu fokus dari kementerian Pendidikan Asia Tenggara (Southeast Asian Ministers of Education Organization). Telah banyak dilakukan pelatihan bagi guru-guru di tingkat Asia Tenggara, termasuk di Indonesia (www.seameo.org). Di Indonesia, STEM menjadi salah satu fokus dalam pendidikan di level perguruan tinggi ditandai dengan hadirnya pusat STEM Indonesia (https://stem.id/).

Beberapa penelitian yang terkait dengan STEM telah banyak dilakukan baik pada level sekolah dasar maupun perguruan tinggi. Slovacek et al. (2019) melakukan studi yang berfokus pada menilai manfaat ekstrakurikuler workshop siswa (di luar kuliah pada umumnya) dan strategi lain yang disediakan oleh program DIRECT-STEM, program dari Universitas California (California State University). Hasil program ini menunjukkan bahwa partisipasi program meningkatkan level minat mahasiswa pada sekolah pascasarjana dan keingininan untuk berkarir di STEM. Kepercayaan diri mahasiswa dalam keberhasilan dan penyelesaian gelar meningkat, para mahasiswa mengembangkan komunitas (sense of community) dalam budaya riset di universitas. Penelitian lain dilakukan Register et al. (2020) menjelaskan bahwa studi tentang matematika pada umumnya berfokus pada penggunaan konteks lokal dengan melibatkan siswa dalam penggunaan matematika untuk membaca dan menulis ulang tentang dunia mereka. Beberapa penelitian telah menyelidiki peran etika dalam kelas matematika. Lebih lanjut Register et al. (2020) mendiskusikan tentang pertimbangan etika yang muncul selama kelas studi design research (penelitian desain) pada siswa-siswa 7 kelas yang diintegrasikan penalaran STEM (STEM reasoning). Hasil dari penelitian ini menunjukkan persepsi siswa terhadap matematika mengindikasikan adanya potensi bahaya buta matematika (STEM) bagi siswa dan peran etika dalam matematika. Dalam penelitian ini diperkenalkan kesadaran STEM kritis sebagai konstruksi baru dalam pendidikan matematika. Penelitian lainnya dilakukan Hourigan \& Leavy (2020) tentang integrasi STEM untuk menyelidiki literasi statistik pada siswa kelas VI SD. Penelitian ini memberikan masalah-masalah STEM yang dapat mendorong siswa mempraktekkan berbagai keterampilan abad 21 seperti kolaborasi, berpikir kritis, dan komunikasi.

Penelitian di Indonesia yang mengaitkan STEM dengan literasi matematis telah dilakukan Mujib et al. (2019) meneliti tentang pengaruh STEM terhadap literasi matematis dan multiple intelligences. Hasil yang diperoleh adalah penggunaan metode STEM memberikan pengaruh 
terhadap literasi matematis mahasiswa. Literasi matematis mahasiswa yang belajar dengan metode STEM lebih baik daripada mahasiswa yang belajar dengan metode non-STEM. Berdasarkan penelitian sebelumnya, kajian mengenai STEM terhadap literasi matematis di tingkat pendidikan tinggi masih minim dilakukan. Hal ini menjadi motivasi bagi peneliti untuk mengkaji kaitan antara STEM dengan literasi matematis di tingkat pendidikan tinggi pada mata kuliah Pra Kalkulus 1. Tujuan dari penelitian ini adalah untuk: (1) mendeskripsikan pembelajaran yang mengintegrasikan STEM pada perkuliahan Pra Kalkulus 1 bagi mahasiswa calon guru matematika pada materi fungsi; (2) mendeskripsikan bagaimana peningkatan literasi matematis mahasiswa calon guru matematika melalui pembelajaran yang terintegrasi STEM; dan (3) mendeskripsikan bagaimana respon mahasiswa calon guru matematika terhadap pembelajaran yang terintegrasi STEM.

\section{METODE PENELITIAN}

Penelitian ini menggunakan metode deskriptif dengan pendekatan kuantitatif dan kualitatif. Nazir (1988) mendefinisikan metode deskriptif adalah prosedur untuk memecahkan masalah dengan cara menggambarkan atau mendeskripsikan keadaan subjek/objek penelitian (orang, lembaga, masyarakat) berdasarkan fakta yang tampak. Dalam penelitian ini dilakukan dengan mendeskripsikan pembelajaran terintegrasi STEM, literasi matematis, dan respon mahasiswa secara verbal yang didukung data numerik. Subjek penelitian ini sebanyak 6 orang mahasiswa calon guru matematika yang mengikuti perkuliahan Pra Kalkulus 1 di STKIP Surya Tangerang pada Tahun Akademik 2019/2020 Semester Ganjil.

Instrumen dalam penelitian ini terdiri dari tes literasi matematis dan angket respon mahasiswa terhadap pembelajaran. Instrumen tes literasi matematis terdiri dari 7 butir soal yang memuat indikator literasi matematis dalam aspek STEM pada materi fungsi. Indikator literasi matematis mengacu pada Association of America Colleges and Universities (AAC\&U) yang merinci literasi matematis ke dalam enam indikator, yaitu: (1) interpretasi; (2) representasi; (3) kalkulasi; (4) asumsi; (5) aplikasi/analisis; dan (6) komunikasi (Rafianti et al., 2018). Instrumen tes ini disusun peneliti kemudian dilakukan validasi ahli oleh salah satu dosen pada Program Studi Pendidikan Matematika STKIP Surya untuk memeriksa keterbacaan soal. Masukan dari validator digunakan sebagai bahan perbaikan instrumen tes ini. Pemberian skor dengan menggunakan pedoman skor the quantity rubric score from Association of American Colleges yang telah dimodifikasi Rafianti et al. (2018), yaitu skor maksimal tiap butir adalah 2 (skor 0 jika tidak mampu memberikan respon jawaban, skor 1 jika mampu memberi respon jawaban namun ada beberapa kekeliruan, dan skor 2 jika mampu memberikan respon jawaban dengan tepat). Kisi-kisi instrumen tes literasi matematis disajikan pada Tabel 1.

Tabel 1. Kisi-kisi literasi matematis dalam aplikasi STEM

\begin{tabular}{llcc}
\hline \multicolumn{1}{c}{ Unsur soal } & \multicolumn{1}{c}{ Aspek literasi matematis } & Aplikasi STEM & Nomor Soal \\
\hline Fungsi yang didefinisikan piecewise & a. Interpretasi & Matematika & 1 \\
& b. Kalkulasi & & \\
Hukum Toricelli & c. Representasi & Sains & 2 \\
& a. Kalkulasi & & \\
& b. Interpretasi & & \\
Designing roller coaster & c. Representasi & Rekayasa dan & 3 \\
& a. Asumsi & Teknologi & \\
& b. Kalkulasi & & \\
& c. Mathematical deductions & & \\
& d. Asumsi & & \\
Fungsi dengan Grafiknya & e. Representasi & & \\
Menggambar Grafik dengan Alat Bantu & f. Kalkulasi & Matematika & 4 \\
(Aplikasi Geogebra Graphing Calculator) & Aplikasi/ Analisis & Teknologi & 5 \\
\hline
\end{tabular}


Lanjutan Tabel 1

Tabel 1. Kisi-kisi literasi matematis dalam aplikasi STEM

\begin{tabular}{|c|c|c|c|}
\hline Unsur soal & Aspek literasi matematis & Aplikasi STEM & Nomor Soal \\
\hline Grafik fungsi nilai mutlak & $\begin{array}{l}\text { a. Representasi dan } \\
\text { analisis } \\
\text { b. Representasi dan } \\
\text { analisis } \\
\text { c. Analisis }\end{array}$ & Matematika & 6 \\
\hline Tenaga dari turbin angin & Representasi & & 7 \\
\hline
\end{tabular}

Adapun contoh soal literasi matematis yang terintegrasi STEM pada materi fungsi dapat dilihat pada Tabel 2.

Tabel 2. Contoh soal instrumen tes literasi matematis terintegrasi STEM

\begin{tabular}{cl}
\hline Nomor & Soal \\
\hline 1 & Diketahui suatu fungsi yang didefinisikan. \\
& $f(x)=\left\{\begin{array}{cc}x^{2} & \text { jika } x<0 \\
x+1 & \text { jika } x \geq 0\end{array}\right.$ \\
& a. Apakah domain dari $f(x)$ \\
& b. Carilah nilai dari $f(-2), f(-1), f(0), f(2)$ \\
& c. Gambarkanlah grafik fungsi $f(x)$ \\
& Sebuah tangki menampung 50 galon air mengalir dari \\
& kebocoraan di bagian bawah, yang dapat menyebabkan tangki \\
& kosong dalam 20 menit. Tangki mengering lebih cepat ketika \\
& hampir penuh karena tekanan pada kebocoran lebih besar. \\
& Hukum Torricelli memberikan volume air yang tersisa di tangki \\
& setelah $t$ menit sebagai: \\
& $V(t)=50\left(1-\frac{t}{20}\right)^{2}, 0 \leq t \leq 20$ \\
& a. $\quad$ Carilah nilai dari $V(0)$ dan $V(20)$ \\
b. Jawaban kamu pada poin $(a)$ mewakili apakah? & C. Buat tabel nilai-nilai dari $V(t)$ untuk $t=0,5,10,15,20$.
\end{tabular}

Instrumen angket terdiri dari 30 butir pernyataan yang memuat minat, pendapat, dan manfaat mahasiswa setelah mengikuti perkuliahan yang terintegrasi STEM. Instrumen angket dikembangkan peneliti, selanjutnya dilakukan proses validasi ahli oleh dosen Program Studi Pendidikan Matematika STKIP Surya. Angket menggunakan skala Likert dengan kriteria Sangat Setuju (SS), Setuju (S), Tidak Setuju (TS), dan Sangat Tidak Setuju (STS). Pemberian skor angket untuk tipe pernyataan positif adalah 4 untuk SS, 3 untuk S, 2 untuk TS, dan 1 untuk STS, demikian sebaliknya untuk tipe pernyataan negatif. Instrumen angket yang dikembangkan mengikuti kisi-kisi seperti pada Tabel 3.

Tabel 3. Kisi-kisi angket respon mahasiswa terhadap pembelajaran terintegrasi STEM

\begin{tabular}{cll}
\hline No. & \multicolumn{1}{c}{ Sikap Mahasiswa } & \multicolumn{1}{c}{ Indikator } \\
\hline 1. & Terhadap perkuliahan Pra Kalkulus 1 & $\begin{array}{l}\text { Menunjukkan minat untuk mengikuti perkuliahan } \\
\text { Menunjukkan pendapat mahasiswa tentang perkuliahan }\end{array}$ \\
2. & $\begin{array}{l}\text { Terhadap konten materi mata kuliah Pra } \\
\text { Kalkulus 1 }\end{array}$ & $\begin{array}{l}\text { Menunjukkan minat terhadap materi perkuliahan } \\
\text { Menunjukkan pendapat terhadap materi perkuliahan } \\
\text { 3. }\end{array}$ \\
$\begin{array}{l}\text { Terhadap latihan soal mata kuliah Pra } \\
\text { Kalkulus 1 }\end{array}$ & $\begin{array}{l}\text { Menunjukkan pendapat terhadap latihan soal perkuliahan } \\
\text { Menunjukkan manfaat terhadap latihan soal perkuliahan }\end{array}$ \\
\hline
\end{tabular}

Teknik analisis data pada penelitian ini menggunakan analisis deskriptif kuantitatif. Data tes digunakan untuk melihat peningkatan (gain) skor berupa selisih antara skor pretest dan posttest. Selanjutnya untuk menentukan kriteria kemampuan berada pada level tinggi, sedang atau rendah, digunakan pedoman dengan kategori: tinggi jika $x \geq \bar{x}+S D$, sedang jika $\bar{x}-S D<x<\bar{x}+S D$, dan rendah jika $x \leq \bar{x}-S D$ (Arikunto, 2012). Analisis data angket menggunakan rekapitulasi skor, 
kemudian dihitung besarnya persentase respon mahasiswa. Selanjutnya, persentase respon mahasiswa diidentifikasi termasuk kategori respon sangat positif, positif, kurang positif, atau tidak positif (negatif). Pedoman pengategorian respon tersebut mengacu pada Khabibah (Zaahirah, 2014), yaitu sangat positif jika $R s \geq 85$, positif jika $70 \leq R s<85$, kurang positif jika $50 \leq R s<70$, dan tidak positif jika $R s<50$ (dengan $R s=$ persentase respon mahasiswa).

\section{HASIL DAN PEMBAHASAN}

Tujuan penelitian ini adalah untuk: (1) mendeskripsikan pembelajaran yang terintegrasi STEM pada perkuliahan Pra Kalkulus 1 bagi mahasiswa calon guru matematika pada materi fungsi; (2) mendeskripsikan peningkatan literasi matematis mahasiswa calon guru matematika melalui pembelajaran yang terintegrasi STEM; dan (3) mendeskripsikan respon mahasiswa calon guru matematika terhadap pembelajaran yang terintegrasi STEM.

\section{Pembelajaran dengan Integrasi STEM}

Penelitian ini dilakukan dengan memberikan pembelajaran terintegrasi STEM bagi mahasiswa calon guru matematika di STKIP Surya pada perkuliahan Pra Kalkulus 1 untuk materi fungsi. Materi perkuliahan meliputi submateri: (1) Apa itu fungsi?; (2) Grafik fungsi; (3) Memperoleh informasi dari grafik sebuah fungsi; (4) Nilai rata-rata perubahan fungsi; (5) Transformasi fungsi; (6) Fungsi kombinasi/komposisi; dan (7) Fungsi satu-satu dan inversnya. Materi yang diajarkan menggunakan modul yang ditulis oleh peneliti dengan mengacu pada buku Precalculus Sixth Edition (Stewart et al., 2012). Modul yang disusun menyampaikan konsep-konsep tentang fungsi disertai berbagai implementasinya dalam bidang sains, bidang teknologi, bidang rekayasa/teknik, dan bidang matematika. Proses pembelajaran dilakukan dengan penjelasan secara ceramah dan demonstrasi, eksplorasi, latihan, penugasan, dan penugasan proyek.

Pada bagian penjelasan materi, pembelajaran dilakukan dengan memberikan permasalahan dari konteks dunia nyata yang terkait dengan bidang sains, teknik, dan matematika sebelum menjelaskan konsep matematika. Setelah mahasiswa menguasai konsep yang disampaikan, diberikan latihan dan penugasan terkait bidang-bidang tersebut. Contoh konteks dan implementasi pembelajaran STEM materi fungsi pada bidang sains dapat dilihat pada Gambar 1.

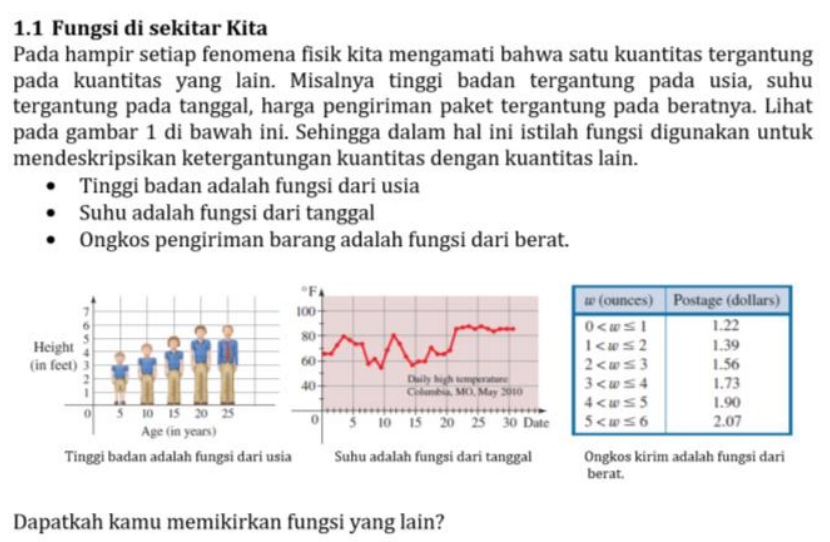

(a) Pembentukan konsep melalui konteks sains

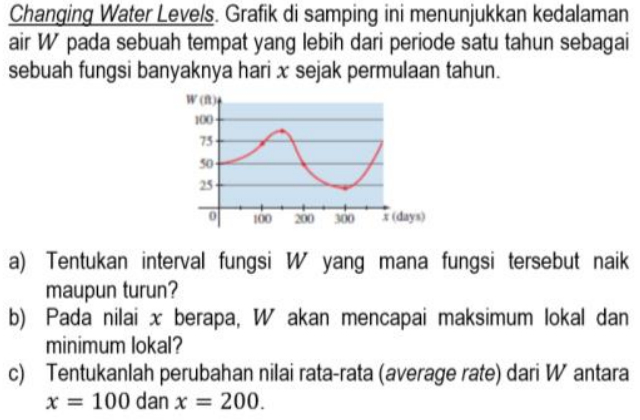
air $W$ pada sebuah tempat yang lebih dari periode satu tahun sebagai sebuah fungsi banyaknya hari $x$ sejak permulaan tahun.

a) Tentukan interval fungsi $W$ yang mana fungsi tersebut naik maupun turun?

b) Pada nilai $x$ berapa, $W$ akan mencapai maksimum lokal dan minimum lokal?

c) Tentukanlah perubahan nilai rata-rata (average rate) dari $W$ antara $x=100$ dan $x=200$.

(b) Latihan dalam aplikasi sains

Gambar 1. Pembelajaran STEM materi fungsi pada bidang sains

Pembelajaran melalui pemberian konteks-konteks terkait materi fungsi pada bidang sains, membuat mahasiswa menjadi tahu permasalahan sains di sekitar yang memiliki hubungan dengan fungsi. Ini menunjukkan mahasiswa lebih melek (literate) terhadap materi fungsi yang tidak sekedar simbol-simbol matematis. Mahasiswa diberikan latihan-latihan untuk menajamkan pemahaman dalam bentuk latihan terkait konsep dan implementasi. Mahasiswa memiliki perbendaharaan konteks dan implementasi sains dari materi fungsi yang lebih variatif. 
Integrasi STEM dalam bidang teknik dilakukan dengan memberikan penugasan yang meminta siswa untuk mendesain suatu fungsi melalui persoalan yang diberikan. Persoalan tersebut dapat dilihat pada Gambar 2.

Seandainya kamu diminta untuk merancang pendakian dan penurunan pertama dari sebuah roller coaster. Dengan mempelajari foto-foto coaster, kamu memutuskan untuk membuat kemiringan naik 0,8 dan kemiringan turun -1,6. Kemudian, kamu menghubungkan dua buah garis lurus $y=L_{1}(x)$ dan $y=$ $L_{2}(x)$ sebagai bagian dari parabola

$$
y=f(x)=a x^{2}+b x+c
$$

Dimana $x$ dan $\mathrm{f}(x)$ dalam satuan kaki. Agar trek roller coaster halus (smooth) tidak dapat berubah arah dengan tiba-tiba, sehingga kamu menginginkan segmen garis $L_{1}$ dan $L_{2}$ menjadi garis singgung parabola pada posisi titik $P$ dan $Q$, yang ditunjukkan pada gambar di bawah ini.

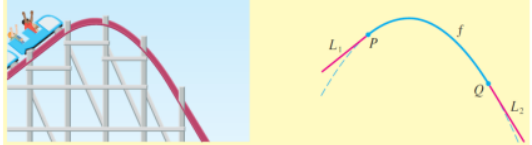

a) Untuk menyederhanakan persamaan, kamu memutuskan untuk menempatkan titik asalnya di $P$. Sebagai konsekuensinya, berapakah nilai $c$ ?

b) Misalkan jarak horisontal antara $P$ dan $Q$ adalah 100 kaki. Untuk memastikan bahwa trek halus setiap kali perpindahan titik, berapakah nilai $f^{\prime}(0)$ dan $f^{\prime}(100)$ yang seharusnya?

c) Jika $f(x)=a x^{2}+b x+c$, tunjukkan bahwa $f^{\prime}(x)=2 a x+b$.

d) Gunakan hasil dari masalah 2 dan 3 untuk mendapatkan nilai $a$ dan $b$. Kemudian tentukan formula dari $f(x)$.

e) Plot $L_{1}, f$, dan $L_{2}$ untuk memverfikasi secara grafik bahwa perpindahannya halus.

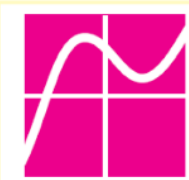

f) Tentukan perbedaan ketinggian/ elevasi (difference in elevation) antara $P \operatorname{dan} Q$.

Gambar 2. Pembelajaran STEM materi fungsi pada bidang teknik/rekayasa

Tujuan memberikan permasalahan ini adalah agar mahasiswa mampu mengidentifkasi persoalan, menemukan masalah yang disajikan, menggunakan informasi dan petunjuk untuk menyelesaikan pertanyaan-pertanyaan yang diajukan. Dalam permasalahan ini, mahasiswa diminta untuk membuat desain fungsi yang melibatkan konsep matematika tentang garis lurus, gradien, persamaan kuadrat, turunan, elevasi dan sketsa grafik.

Pembelajaran STEM untuk bidang matematika dilakukan dalam pembentukan konsepkonsep secara matematis, serta pemberian persoalan yang menyangkut konsep matematika tersebut. Contoh materi pada bidang matematika dapat dilihat pada Gambar 3.

\footnotetext{
1.4 DOMAIN FUNGSI

Kita ingat kembali bahwa domain dari fungsi adalah himpunan dari semua input dari fungsi. Domain dari fungsi dapat dinyatakan secara eksplisit. Sebagai contoh, jika kita menulis

$$
f(x)=x^{2} \quad 0 \leq x \leq 5
$$

Maka domainnya adalah himpunan semua bilangan real $x$ pada interval $0 \leq$ $\boldsymbol{x} \leq \mathbf{5}$. Jika fungsinya diberikan dalam ekspresi aljabar dan domain tidak dinyatakan secara eksplisit, maka domain dari fungsi adalah domain dari ekspresi aljabarnya yang didefinisikan sebagai bilangan riil. Sebagai contoh perhatikan fungsi berikut.

$$
f(x)=\frac{1}{x-4}, \quad g(x)=\sqrt{x}
$$

Fungsi $f$ tidak didefinisikan pada $x=4$, sehingga domainnya adalah $\{x \mid x \neq 4\}$. Fungsi $g$ tidak didefinisikan untuk $x$ negatif, sehingga domainnya adalah $\{x \mid x \geq 0\}$
}

\section{(a) Pembentukan konsep dalam matematika}

Menggunakan sifat fungsi invers untuk menunjukkan bahwa $f$ dan $g$ saling invers:

$$
\begin{array}{ll}
\text { a. } & f(x)=x-6 \text { dan } g(x)=x+6 \\
\text { b. } & f(x)=\frac{3-x}{4} \operatorname{dan} g(x)=3-4 x
\end{array}
$$

Gambar 3. Pembelajaran STEM materi fungsi pada bidang matematika

Pembelajaran yang terintegrasi STEM pada bidang teknologi, peneliti mengarahkan mahasiswa untuk menggunakan aplikasi Geogebra Graphing Calculator pada smartphone yang dapat diunduh secara gratis di playstore. Pemilihan penggunaan aplikasi ini pada smartphone karena mahasiswa sangat dekat dengan smartphone, terampil mengoperasikan smartphone, dan keberadaan smartphone selalu menyertai walaupun tidak sedang dalam kegiatan perkuliahan. 
Aplikasi Geogebra Graphing Calculator berguna untuk menggambar maupun mengeksplorasi grafik fungsi. Penggunaan aplikasi ini melibatkan penggunaan internet untuk mengakses dan mengoerasikannya. Tampilan aplikasi Geogebra Graphing Calculator serta implementasinya dalam menggambar grafik disajikan pada Gambar 4.

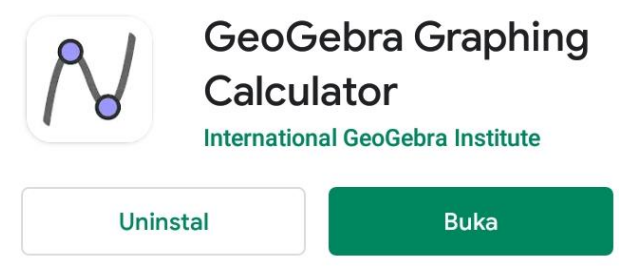

(a) Aplikasi Geogebra Graphing Calculator pada playstore
Gambarkan fungsi $f(x)$ berikut menggunakan Geogebra Graphing Calculator.

$f(x)=\left\{\begin{array}{cc}x^{2} & \text { jika } x \leq 1 \\ 2 x+1 & \text { jika } x>1\end{array}\right.$

Untuk memperoleh gambar grafiknya, digunakan perintah 'Jika $\left(x \leq 1, x^{2}, 2 x+1\right)^{\prime}$, diperoleh output seperti pada gambar.

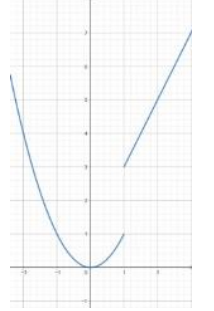

(b) Penggunaan aplikasi geogebra dalam menggambar grafik

Gambar 4. Pembelajaran STEM materi fungsi pada bidang teknologi

Penggunaan aplikasi ini, contohnya dapat memudahkan mahasiswa untuk mendapatkan pengetahuan tentang penampilan visual dari grafik fungsi yang diminta. Selain itu mahasiswa dapat melakukan eksplorasi menggunakan aplikasi Geogebra Graphing Calculator untuk menemukan hubungan-hubungan antar grafik dari fungsi-fungsi yang diberikan. Sehingga, mahasiswa dapat menarik kesimpulan yang tepat tentang hubungan antara beberapa fungsi. Sebagai contoh adalah hubungan dari fungsi-fungsi $y=x, y=x^{3}, y=x^{5}$ dan $y=x^{7}$ atau hubungan dari fungsifungsi $y=x^{2}, y=x^{4}, y=x^{6}$ dan $y=x^{8}$. Di sisi lain, mahasiswa mendapatkan tambahan pengetahuan karena belajar untuk perintah logika yang benar agar dapat menghasilkan grafik fungsi yang tepat.

Pada proses pembelajaran terintegrasi STEM ini, mahasiswa diberikan penugasan untuk mengerjakan jenis discovery project yang dapat diakses pada website www.stewartmath.com. Pemberian discovery project pada penelitian ini bertujuan untuk mengasah kemampuan mahasiswa dalam merekayasa suatu permasalahan matematis. Hal ini berkaitan dengan kemampuan dalam bidang teknik/rekayasa. Discovery project disini merupakan proyek penemuan yang mengarahkan mahasiswa untuk menemukan konsep dengan mengkonstruksi pengetahuan oleh diri mereka sendiri yang dapat dilakukan dengan diskusi dengan sesama mahasiswa. Pemikiran ini sejalan dengan Mustikaningrum et al. (2016) dalam penjelasan pembelajaran yang berbasis proyek, bahwa dengan belajar berbasis proyek peserta didik diberikan kesempatan untuk membangun pengetahuan dan pemahaman mereka tentang konsep yang pada akhirnya dapat menghasilkan produk. Produk dalam pembelajaran yang diberikan kali ini adalah berupa rancangan matematis untuk menemukan suatu konsep matematika. Salah satu contoh discovery project yang ditugaskan terlihat pada Gambar 5. 


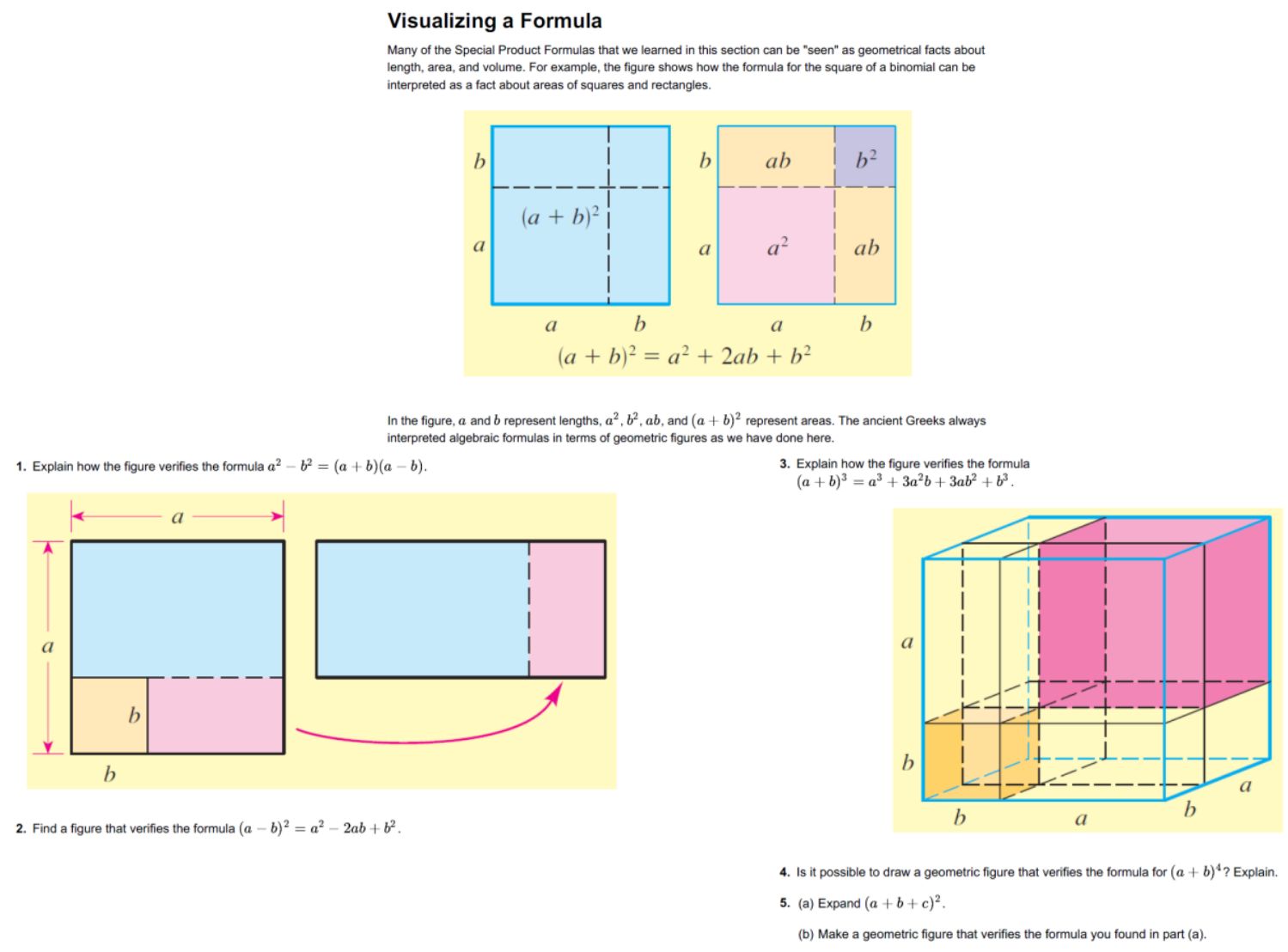

Gambar 5. Contoh discovery project

\section{Literasi Matematis Mahasiswa Calon Guru Matematika}

Untuk melihat besarnya literasi mahasiswa, peneliti memberikan pretest dan posttest kepada mahasiswa. Dari hasil pretest dan posttest, selanjutnya peneliti mencari besarnya peningkatan (gain) bagi masing-masing mahasiswa. Peningkatan dalam hal ini dilihat dengan mencari selisih antara pretest dan posttest. Peningkatan literasi matematis pada penelitian ini dilihat dalam skor dan nilai, dengan nilai dikonversikan dalam skala 100. Hasilnya dapat dilihat pada Tabel 4.

Tabel 4. Skor dan nilai pretest, posttest, dan gain literasi matematis mahasiswa

\begin{tabular}{ccccccc}
\hline \multirow{2}{*}{ Kode Subjek } & \multicolumn{3}{c}{ Skor } & \multicolumn{3}{c}{ Nilai } \\
\cline { 2 - 7 } & Pretest & Posttest & Gain & Pretest & Posttest & Gain \\
\hline S1 & 0 & 13 & 13 & 0 & 28,26 & 28,26 \\
S2 & 20 & 28 & 8 & 43,48 & 60,87 & 17,39 \\
S3 & 11 & 19 & 8 & 23,91 & 41,30 & 17,39 \\
S4 & 15 & 30 & 15 & 32,61 & 65,22 & 32,61 \\
S5 & 17 & 25 & 8 & 36,96 & 54,35 & 17,39 \\
S6 & 17 & 33 & 16 & 36,96 & 71,74 & 34,78 \\
Rata-rata & 13,3 & 24,7 & 11,33 & 29,0 & 53,6 & 24,6 \\
Standar Deviasi & 7,2 & 7,4 & 3,78 & 15,6 & 16,2 & 8,2 \\
\hline
\end{tabular}

Skor-skor dan nilai dari pretest, posttest, dan peningkatan literasi matematis mahasiswa calon guru matematika dapat diamati secara rinci pada tabel di atas. Skor ideal yang diperoleh pada tes ini adalah 46. Sehingga diperoleh rata-rata skor pretest literasi matematis sebesar 13,3 dan rata-rata skor posttest literasi matematis sebesar 24,7. Untuk peningkatan diperoleh rata-rata skor sebesar 11,33 dan standar deviasi sebesar 3,78. Untuk melihat besarnya persentase penguasaan literasi matematis dapat dilihat pada kolom nilai, sehingga tampak penguasaan literasi matematis mahasiswa pada pretest sebesar $29 \%$, posttest sebesar $53,6 \%$, dan peningkatannya sebesar $24,6 \%$. 
Secara numerik, kita tahu bahwa peningkatan literasi matematis mahasiswa sebesar 24,6\% dengan rata-rata skor peningkatan 3,78. Selanjutnya akan dilihat ketegori dari peningkatan ini. Skorskor pada Tabel 4 dibuat batasan interval (sesuai penjelasan pada subbab metode penelitian) untuk melihat peningkatan ini berada pada kategori tinggi, sedang, atau rendah. Batasan interval kategori peningkatan literasi matematis pada penelitian ini ditampilkan pada Tabel 5.

Tabel 5. Kategori literasi matematis mahasiswa

\begin{tabular}{ccc}
\hline Kategori & Batas interval & Batas literasi matematis \\
\hline Tinggi & $x \geq \bar{x}+S D$ & $x \geq 32,8$ \\
\hline Sedang & $\bar{x}-S D<x<\bar{x}+S D$ & $16,4<x<32,8$ \\
\hline Rendah & $x \leq \bar{x}-S D$ & $x \leq 16,4$ \\
\hline
\end{tabular}

Mengacu pada tabel di atas kita dapatkan hasil bahwa literasi matematis mahasiswa pada penelitian ini berada pada kategori sedang. Agar gap antara pretest, posttest, dan gain literasi matematis pada tiap-tiap mahasiswa dapat terlihat lebih jelas, peneliti menyajikan diagram pada Gambar 6.

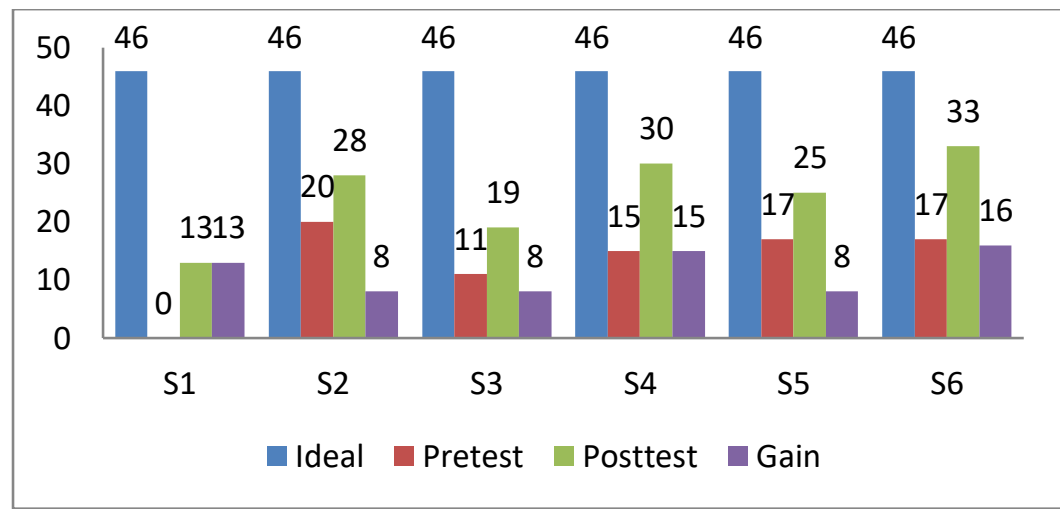

Gambar 6. Skor pretest, posttest, dan gain pada literasi matematis mahasiswa

Untuk penguasaan literasi matematis, dapat dilihat penguasaan perbutir yang teruraikan dalam poin-poin. Penguasaan literasi matematis tertinggi terjadi pada subjek S6 dengan skor posttest sebesar 33 dan skor peningkatannya sebesar 16 . Sedangkan yang terendah terjadi pada subjek S1 dengan skor posttest sebesar 13. Pada subjek S1 peningkatan yang diperoleh sama dengan skor posttest, namun peningkatan ini bukan yang terendah. Peningkatan terendah terjadi pada S2, S3, dan S5 dengan skor peningkatan sebesar 8.

Dari uraian-uraian di atas, kita sudah tahu bahwa literasi matematis mahasiswa pada penelitian ini berada pada kategori sedang. Selain itu kita juga sudah tahu subjek penelitian yang memiliki literasi matematis tinggi dan rendah. Selanjutnya, akan dilihat penguasaan literasi matematis mahasiswa jika berdasarkan butir soal yang dapat dilihat per-butir soal. Penguasaan literasi matematis pada pretest dan posttest berdasarkan indikator disajikan pada Tabel 6 dan Tabel 7.

Tabel 6. Skor literasi matematis per-butir soal pada pretest

\begin{tabular}{|c|c|c|c|c|c|c|c|c|c|c|c|c|c|c|c|c|c|c|c|c|c|c|c|}
\hline \multirow{3}{*}{ Istilah } & \multicolumn{23}{|c|}{ Skor Butir Soal } \\
\hline & \multicolumn{3}{|c|}{1} & \multicolumn{3}{|c|}{2} & \multicolumn{6}{|c|}{3} & \multicolumn{4}{|c|}{4} & \multirow{2}{*}{5} & \multicolumn{5}{|c|}{6} & \multirow{2}{*}{7} \\
\hline & 1a & $1 \mathrm{~b}$ & $1 \mathrm{c}$ & $2 a$ & $2 b$ & $2 c$ & $3 a$ & $3 \mathrm{~b}$ & $3 c$ & $3 d$ & $3 \mathrm{e}$ & $3 f$ & $4 a$ & $4 b$ & $4 c$ & $4 d$ & & a1 & a2 & b1 1 & b2 & c & \\
\hline Jumlah Skor Per Nomor Soal & 1 & 0 & 0 & 2 & 0 & 0 & 3 & 0 & 0 & 0 & 0 & 0 & 4 & 0 & 0 & 0 & 5 & 6 & 0 & 0 & 0 & 0 & 7 \\
\hline Skor Ideal Per Nomor Soal & 12 & 12 & 12 & 12 & 12 & 12 & 12 & 12 & 12 & 12 & 12 & 12 & 12 & 12 & 12 & 12 & 12 & 12 & 12 & 12 & 12 & 12 & 12 \\
\hline Penguasaan Per Nomor Soal (\%) & 8,3 & 0 & 0 & 16,7 & 0 & 0 & 25 & 0 & 0 & 0 & 0 & 0 & 33 & 0 & 0 & 0 & 41,7 & 50 & 0 & 0 & 0 & 0 & 58,3 \\
\hline Rata-rata Penguasaan Per Butir (\%) & & 2,78 & & & 5,56 & & & & 5 & & & & & 8,3 & & & 41,7 & & & 10 & & & 58,3 \\
\hline
\end{tabular}


Tabel 7. Skor literasi matematis per-butir soal pada posttest

\begin{tabular}{|c|c|c|c|c|c|c|c|c|c|c|c|c|c|c|c|c|c|c|c|c|c|c|c|}
\hline \multirow{3}{*}{ Istilah } & \multicolumn{23}{|c|}{ Skor Butir Soal } \\
\hline & \multicolumn{3}{|c|}{1} & \multicolumn{3}{|c|}{2} & \multicolumn{6}{|c|}{3} & \multicolumn{4}{|c|}{4} & \multirow{2}{*}{5} & \multicolumn{5}{|c|}{6} & \multirow{2}{*}{7} \\
\hline & 1a & $1 b$ & $1 \mathrm{c}$ & $2 a$ & $2 \mathrm{~b}$ & $2 c$ & $3 a$ & $3 \mathrm{~b}$ & $3 c$ & $3 d$ & $3 \mathrm{e}$ & $3 f$ & $4 a$ & $4 \mathrm{~b}$ & $4 \mathrm{c}$ & $4 d$ & & a1 & a2 & b1 & b2 & c & \\
\hline Jumlah Skor Per Nomor Soal & 8 & 8 & 8 & 9 & 6 & 8 & 4 & 2 & 0 & 0 & 0 & 0 & 12 & 12 & 12 & 12 & 8 & 9 & 7 & 7 & 7 & 7 & 2 \\
\hline Skor Ideal Per Nomor Soal & 12 & 12 & 12 & 12 & 12 & 12 & 12 & 12 & 12 & 12 & 12 & 12 & 12 & 12 & 12 & 12 & 12 & 12 & 12 & 12 & 12 & 12 & 12 \\
\hline Penguasaan Per Nomor Soal (\%) & 66,7 & 66,7 & 66,7 & 75 & 50 & 66,7 & 33 & 17 & 0 & 0 & 0 & 0 & 100 & 100 & 100 & 100 & 66,7 & 75 & 58,3 & 58,3 & 58 & 58 & 16,7 \\
\hline Rata-rata Penguasaan Per Butir (\%) & & 66,7 & & & 63,89 & & & & 3,3 & & & & & 10 & & & 66,7 & & & 61,7 & & & 16,7 \\
\hline
\end{tabular}

Berdasarkan pada tabel-tabel di atas, jika dilihat dari perolehan jawaban mahasiswa menurut butir soal persentase penguasaan literasi matematis yang lebih dari $60 \%$ terdapat pada soal nomor 1 , 2, 4, 5, dan 6. Persentase 100\% diperoleh pada aplikasi STEM bidang matematika dengan indikator literasi matematis aplikasi/analisis. Secara umum para mahasiswa sudah memiliki literasi matematis pada indikator kalkulasi, interpretasi, representasi, dan aplikasi/analisis (meskipin belum maksimal), namun untuk indikator asumsi belum muncul. Mahasiswa juga sudah pembelajaran yang terintegrasi ke dalam bidang sains, teknologi, dan matematika itu sendiri dapat dikuasai dengan cukup, namun tidak untuk bidang teknik.

Dalam pemaparan hasil penelitian ini akan ditampilkan contoh pertanyaan dan jawaban mahasiswa. Misalnya nomor 3 yang memiliki skor posttest paling rendah. Pertanyaan yang diajukan berkaitan dengan implementasi STEM pada bidang engineering disajikan pada Tabel 8 .

Tabel 8. Contoh pertanyaan, indikator literasi matematis, dan jawaban nomor 3

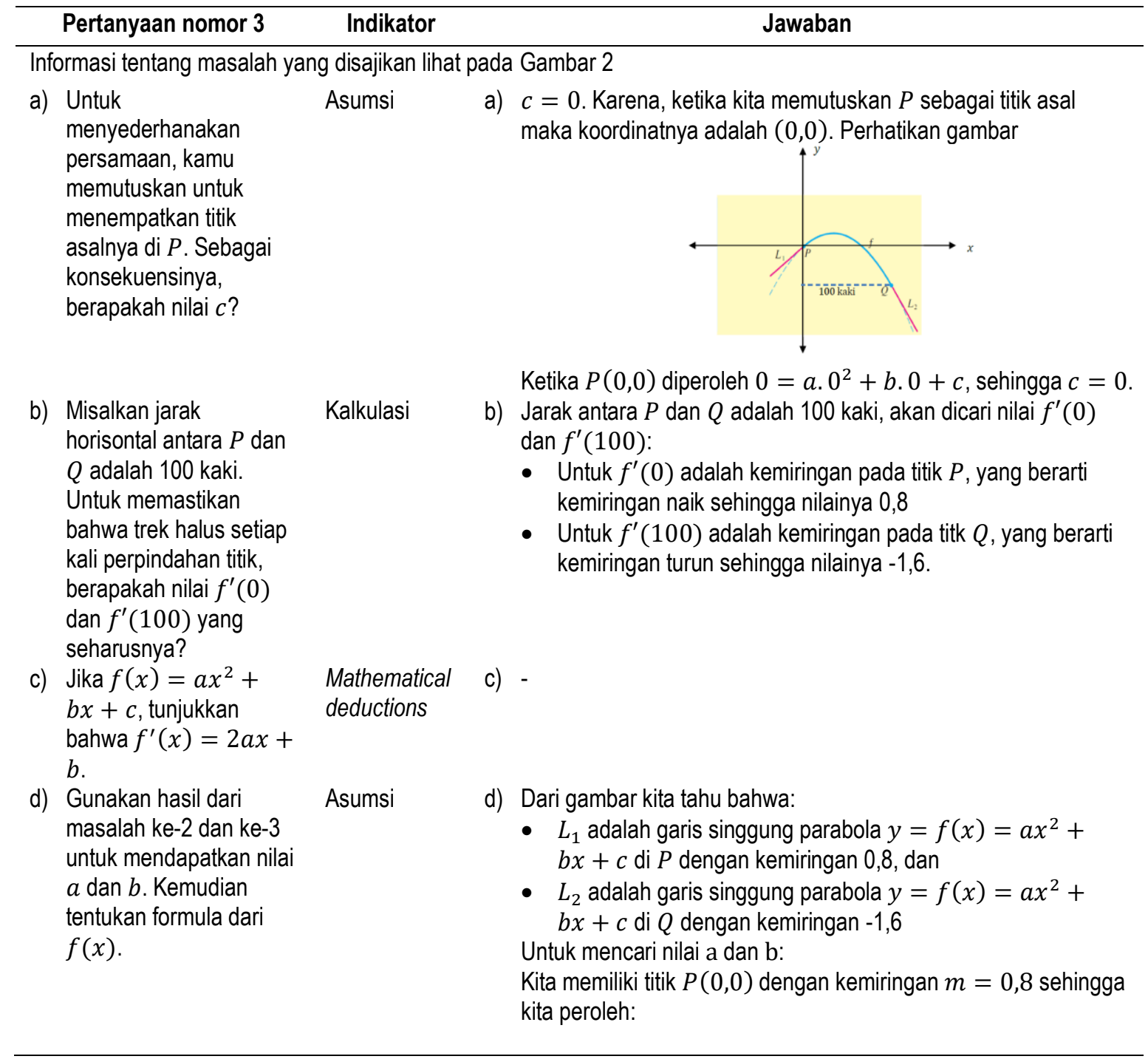


Lanjutan Tabel 8

Tabel 8. Contoh pertanyaan, indikator literasi matematis, dan jawaban nomor 3

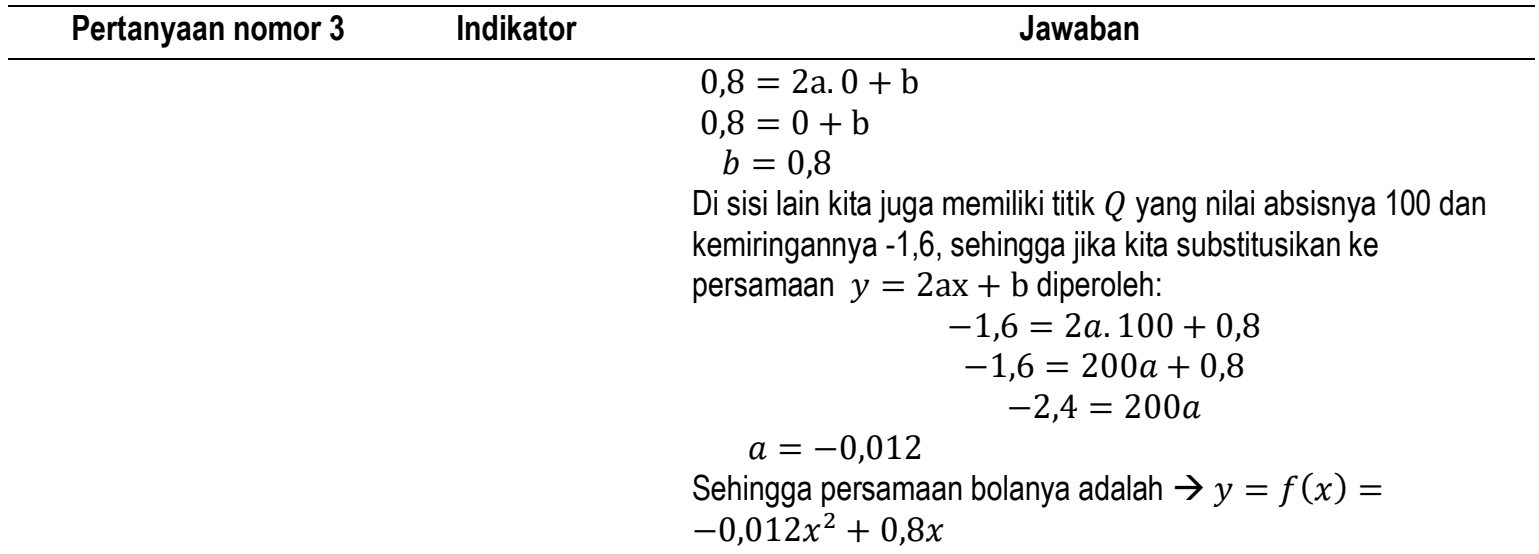

e) Plot $L_{1}, f$, dan $L_{2}$ untuk Representasi e) memverfikasi secara grafik bahwa perpindahannya halus.

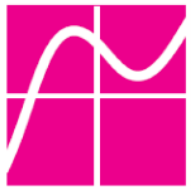

)

Titik-titik potongnya

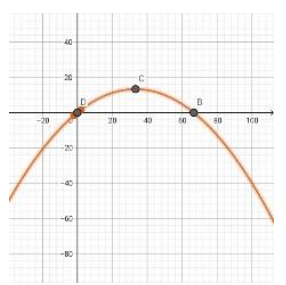

- $\quad$ Titik potong terhadap sumbu= $x \rightarrow(66.7,0)$ dan $(0,0)$

- $\quad$ Titik ekstrim $(33.33,13,33)$

f) Tentukan perbedaan Kalkulasi ketinggian/ elevasi (difference in elevation) antara $P$ dan $Q$.

f) Elevasi antara $P$ dan $Q$ diperoleh ketika absisnya 100. Sehingga akan dicari nilai $f(100)=$

$$
\begin{gathered}
f(100)=-0,012 \cdot 100^{2}+0,8 \cdot 100 \\
=-120+80 \\
=-40
\end{gathered}
$$

Dengan demikian elevasi antara $P$ dan $Q$ adalah 40 kaki.

Contoh hasil pekerjaan mahasiswa dalam bidang engineering subjek S6 memperlihatkan bahwa literasi matematisnya masih belum muncul. Berdasarkan hasil jawaban tes, dari indikator literasi matematis kalkulasi, asumsi, dan representasi, mahasiswa yang bersangkutan baru memiliki sebagian kemampuan asumsi disajikan pada Gambar 7.

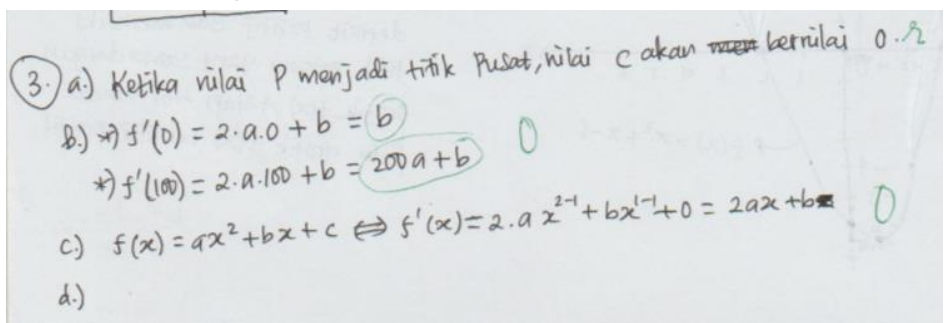

Gambar 7. Jawaban subjek S6 untuk pertanyaan nomor 3

Mahasiswa lain cenderung tidak memberikan jawaban atas pertanyaan ini sehingga dapat dijustifikasi bahwa mahasiswa belum memiliki literasi matematis untuk indikator asumsi, kalkulasi, dan representasi dalam bidang engineering. 


\section{Respon Mahasiswa terhadap Pembelajaran Terintegrasi STEM}

Pemberian angket dalam penelitian ini bertujuan untuk melihat bagaimana respon mahasiswa terhadap pembelajaran terintegrasi STEM yang dilakukan. Hasil perhitungan angket respon mahasiswa yang diperoleh dapat dilihat pada Tabel 9 .

Tabel 9. Skor dan persentase respon mahasiswa terhadap pembelajaran terintegrasi STEM

\begin{tabular}{clccc}
\hline \multirow{2}{*}{ No. } & \multicolumn{2}{|}{ Respon Mahasiswa } & \multicolumn{3}{c}{ Skor } \\
\cline { 3 - 5 } & & Jumlah & Ideal & Persentase (\%) \\
\hline 1. & Terhadap perkuliahan mata kuliah pra kalkulus 1 & 84 & 96 & 87,5 \\
2. & Terhadap konten materi mata kuliah pra kalkulus 1 & 353 & 432 & 81,71 \\
3. & Terhadap latihan soal mata kuliah pra kalkulus 1 & 154 & 192 & 80,21 \\
\hline
\end{tabular}

Berdasarkan tabel di atas, rata-rata persentase respon mahasiswa terhadap pembelajaran yang terintegrasi STEM, diperoleh respon mahasiswa sebesar $83,14 \%$. Menurut pedoman yang ditetapkan peneliti, hal ini menunjukkan bahwa mahasiswa memberikan respon positif terhadap pembelajaran yang diberikan.

\section{Pembahasan}

Dari uraian pada hasil penelitian, pembelajaran terintegrasi STEM disampaikan pada materi fungsi melalui konteks bidang sains, teknik, dan matematika baik dalam membangun konsep maupun implementasinya. Pembelajaran matematika dengan melibatkan konteks tidak langsung memberikan kemudahan bagi siswa dalam belajar, namun dapat memberikan pengalaman belajar yang berbeda yang dapat mempengaruhi interpretasi peserta didik terhadap konteks (Carraher \& Schliemann, 2002; Widjaya, 2013). Dalam penelitian ini, pembelajaran terintegrasi STEM telah memberikan pengalaman belajar yang baru bagi para mahasiswa dengan hadirnya konteks pada bidang sains, teknologi, teknik, dan matematika.

Pembelajaran terintegrasi STEM pada penelitian ini juga menggunakan produk teknologi berupa aplikasi android Geogebra Graphing Calculator untuk memudahkan mahasiswa dalam menggambar dan mengeksplorasi grafik-grafik dengan mudah, sehingga pembelajaran menjadi lebih efektif dan efisien. Hal ini sejalan dengan hasil penelitian Raja \& Nagasubramani (2018) bahwa belajar yang melibatkan teknologi membuat proses transfer ilmu menjadi sangat mudah dan nyaman serta efektif. Lebih lanjut, perolehan dan penyerapan pengetahuan bagi peserta didik menjadi lebih optimal dan sesuai bagaimana objek ilmu pengetahuan itu seharusnya dipelajari. Selain itu pembelajaran dengan melibatkan penggunaan teknologi dapat membuat siswa aktif dalam belajar. Hal ini masih sejalan dengan Raja \& Nagasubramani (2018) yang menyebutkan bahwa salah satu dampak positif dari teknologi dalam dunia pendidikan adalah adanya pembelajaran aktif (active learning). Peralatan teknologi dapat membantu peserta didik dalam memeriksa dan menganalisis informasi yang diperoleh yang terkomputerisasi dan dibuat dengan mudah.

Pra kalkulus merupakan bagian dari bidang ilmu kalkulus. Integrasi STEM dalam pembelajaran pra kalkulus sangat relevan dalam meningkatkan kognitif mahasiswa. Khairani et al. (2018) menyatakan dengan mengimplementasikan STEM pada perkuliahan kalkulus memberikan hasil kognitif siswa meningkat yaitu kognitif dalam kemampuan koneksi dan komunikasi matematis. Demikian pula pada penelitian ini, mahasiswa memiliki peningkatan kognitif, dalam hal ini literasi matematis. Peningkatan literasi matematis mahasiswa yang mengikuti pembelajaran terintegrasi STEM berada pada kategori sedang.

Mahasiswa cenderung mampu menguasai literasi matematis untuk indikator interpretasi, representasi, kalkulasi dan aplikasi/analisis. Ini artinya mahasiswa mampu menguasai literasi dengan cukup dalam hal: (1) bernalar menggunakan data, membaca grafik, menggambarkan kesimpulan, dan mengenali sumber kesalahan; (2) mengubah informasi yang relevan ke dalam bentuk matematis seperti kalimat verbal, persamaan, diagram, dan grafik; (3) mengerjakan hitungan termasuk memanipulasi bilangan-bilangan dan lambang-lambang matematika; dan (4) membuat penilaian yang tepat dan menarik kesimpulan berdasarkan pada analisis kuantitatif data. Hasil ini selaras dengan 
penelitian Rafianti et al (2018) bahwa mahasiswa berhasil menguasai literasi matematis dengan indikator-indikator tersebut. Akan tetapi mahasiswa belum memiliki literasi matematis indikator asumsi, yang artinya mahasiswa belum mampu membuat dan mengevaluasi asumsi-asumsi penting dalam estimasi, pemodelan, analisis data.

Mahasiswa pada perkuliahan pra kalkulus ini, memberikan respon yang positif terhadap pembelajaran terintegrasi STEM. Hasil yang serupa juga diperoleh dari penelitian yang dilakukan oleh (Yilridim \& Sidekli, 2018) bahwa para mahasiswa calon guru memberikan respon terhadap pembelajaran terintegrasi STEM dapat memberikan dampak positif terhadap literasi mahasiswa.

Dari beberapa kelebihan tentang integrasi STEM dalam pembelajaran, ternyata masih dijumpai beberapa hal yang kurang maksimal dalam pembelajaran. Mahasiswa terlihat kurang familiar dengan masalah-masalah penerapan khususnya dalam bidang teknik dan sains. Selain itu, mahasiswa juga tampak kurang mampu memaksimalkan penggunaan aplikasi Geogebra Graphing Calculator pada smartphone, sehingga pengajar harus memandu penggunaan aplikasi tersebut dan memberikan contoh-contoh terutama dalam membuat perintah logika.

\section{KESIMPULAN}

Berdasarkan hasil penelitian dan pembahasan yang telah diuraikan pada paparan sebelumnya maka dapat diperoleh kesimpulan beberapa hal, yaitu: (1) pembelajaran pra kalkulus materi fungsi terintegrasi STEM bagi mahasiswa calon guru disampaikan konsep-konsep diawali dari konteks dan juga implementasinya dalam bidang sains, teknologi, rekayasa/teknik, dan matematika melalui proses pembelajaran secara ceramah, demonstrasi, eksplorasi, latihan, dan penugasan proyek; (2) mahasiswa memiliki penguasaan literasi matematis sebesar $53,6 \%$ dan peningkatan sebesar 24,6\% dengan kategori peningkatan sedang; dan (3) mahasiswa memberikan respon positif terhadap pembelajaran terintegrasi STEM untuk meningkatkan literasi matematis dengan persentase respon sebesar $83,14 \%$.

\section{REKOMENDASI}

Dalam perkuliahan pendidikan matematika, penggunaan aplikasi teknologi untuk pembelajaran yang dapat diakses melalui smartphone sangat membantu memudahkan pemahaman mahasiswa terutama dalam membuat grafik atau mencari hubungan antar grafik. Untuk itu, penggunaan produk teknologi dalam pembelajaran bagi mahasiswa perlu dikembangkan, hal ini juga dapat membuat mahasiswa melek terhadap teknologi.

\section{UCAPAN TERIMAKASIH}

Penulis mengucapkan terima kasih kepada STKIP Surya yang telah memberi dukungan sarana dan prasarana penunjang penelitian. Selain itu juga kepada mahasiswa angkatan 2015 yang mengontrak mata kuliah pra kalkulus 1 Tahun Akademik 2019/2020 semester ganjil yang telah bersedia menjadi subjek penelitian. Ucapan terima kasih juga penulis sampaikan kepada rekan dosen pada Program Studi Pendidikan Matematika STKIP Surya atas sharing materi dan instrumen guna mendukung penelitian ini.

\section{DAFTAR PUSTAKA}

Ahmad, D., Suherman, S. \& Maulana, H. (2018). Teacher mathematical literacy: Case study of junior high school teachers in pasaman. ICOMSET: IOP Conf. Series: Material science and engineering 335, 4-5. doi:10.1088/1757-899X/335/1/011001.

Arikunto, S. (2012). Dasar-dasar evaluasi pendidikan. Jakarta: Bumi Aksara. 
Bolstad, O. H. (2020). Secondary teachers' operationalisation of mathematical literacy. Europian Journal of Science and Mathematics Education, 8(3), 115-135. Doi: https://doi.org/10.30935/scimath/9551.

Carraher, D. \& Schliemann, A. D. (2002). Is everyday mathematics truly relevant to mathematics education. Journal for Research in Mathematics Education Monograph, 11, 131-152. Doi: https://doi.org/10.2307/749968.

Genc, M. \& Erbas, A. K. (2019). Secondory mathematics teachers' conceptions of mathematical literacy. International Journal of Education in Mathematics, Science, and Technology (IJEMST), 7(3), 222-237.

Handelsman, J. \& Smith, M. (2016). Summary: The administration is working to expand STEM education and employment opportunities to all students. [Online]. Tersedia: https://obamawhitehouse.archives.gov/blog/2016/02/11/stem-all [21 Februari 2021].

Harisman, Y., \& Amam, A. (2020). Newman's error analysis terhadap kesalahan mahasiswa pada mata kuliah logika dan himpunan. Teorema: Teori dan Riset Matematika, 5(2), 223-229. Doi: http://dx.doi.org/10.25157/teorema.v5i2.3681.

Hourigan, M. \& Leavy, A. M. (2020). Using integrated STEM as a stimulus to develop elementary students' statistical literacy. Teaching Statistics, 4(3), 77-86. Doi: https://doi.org/10.1111/test.12229.

Khairani, M., \& Aini, F. Q. (2018). Pembelajran berbasis STEM dalam perkuliahan kalkulus di perguruan tinggi. UJMES: Uninus Journal of Mathematics Education and Science, 3(2), 104-111. https://core.ac.uk/download/pdf/228601223.pdf.

Ehmke, T., Wild, E., \& Muller-Kalhoff, T. (2005). Comparing adult mathematical literacy with PISA students: Results of pilot study. Zentralblatt füur Didaktik der Mathematik, 37(3), 159-167. Doi: https://doi.org/10.1007/s11858-005-0005-5.

Kusuma, D. A. (2020). Dampak penerapan pembelajaran daring terhadap kemandirian belajar (self regulated learning) mahasiswa pada mata kuliah geometri selama pembelajaran jarak jauh di masa pandemi covid-19. Teorema: Teori dan Riset Matematika, 5(2), 169-175. Doi: http://dx.doi.org/10.25157/teorema.v5i2.3504

Masjaya \& Wardono. (2018). Pentingnya kemampuan literasi matematika untuk menumbuhkan kemampuan koneksi matematika dalam meningkatkan SDM. PRISMA: Prosiding Seminar Nasional Matematika, Universitas Negeri Semarang. [Online]. Tersedia: https://journal.unnes.ac.id/sju/index.php/prisma/article/view/20196 [28 Oktober 2020].

Mujib, Mardiyah, \& Suherman. (2019). STEM: Pengaruhnya terhadap literasi matematis dan kecerdasan multiple inteligences. Indonesian Journal of Science and Mathematics Education, 3(1), 66-37. Doi: https://doi.org/10.24042/ijsme.v3i1.5448.

Mustikaningrum, D., Maryono, D., \& Yuana, R. A. (2017). The comparison of the discovery learning and project based learning and their influence to student's motivation to learn conditional structure programming. IJIE: Indonesian Journal of Informatics Education, 1(1), 39-43. Doi: https://doi.org/10.20961/ijie.v1i1.4166.

Nazir, M. (1988). Metodologi Penelitian. Jakarta: Ghalia Indonesia. 
OECD. (2014). PISA 2012 result in focus what 15-year-olds know and what they can do with they know. [Online]. Tersedia: https://www.oecd.org/pisa/keyfindings/pisa-2012-resultsoverview.pdf [25 Oktober 2019].

OECD. (2019). PISA 2018 assessment and analytical framework. [Online]. Tersedia: http://www.oecd.org/education/pisa-2018-assessment-and-analytical-frameworkb25efab8-en.htm [25 Oktober 2019]

Rafianti, I., Setiani, Y., \& Novaliyosi, N. (2018). Profil kemampuan literasi kuantitatif calon guru matematika. JPPM: Jurnal Penelitian dan Pembelajaran Matematika, 11(1). Doi: http://dx.doi.org/10.30870/jppm.v11i1.2985.

Raja, R., \& Nagasubramani, P. C. (2018). Impact of modern technology in education. Journal of Applied and Advanced Research. 3, Suppl. 1:S33-S35. Doi:10.21839/jaar.2018.v3iS1.165.

Register, J. T., Pugalenthi, P., \& Stephan, M. (2020). Designing for ethical reasoning in mathematics [and STEM] education. Electronic Journal for Research in Science \& Mathematics Education, 24(2), 141-157.

Sari, R. H. N., \& Wijaya, A. (2017). Mathematical literacy of senior high school students in Yogyakarta. Jurnal Riset Pendidikan Matematika, 4(1). Doi: https://doi.org/10.21831/jrpm.v4i1.10649

SEAMEO. (2019). The signing of SEAMEO STEM-ED and SEPS memorandum of agreement. [Online]. Tersedia: https://www.seameo.org/Main_news/1 [ 24 Februari 2021]

Slovacek, S., Miu, V., Soto, K., \& Ye, H.. (2019). Supporting STEM in higher education. International Journal of Education and Practice, 7(4), 438-449. doi:10.18488/journal.61.2019.74.438.449

Stewart, J., Redlin, L., \& Watson, S. (2012). Precalculus: mathematics for calculus, sixth edition. California: Brooks/Cole, Cengage Learning.

Stewart, J., Redlin, L., Watson, S., \& Panman, P. (2011). Discovery project: visualizing a formula. Doi: https://stewartmath.com/dp_fops_samples/dp1.html.

The National Research Council. (2011). Successful K-12 STEM education: identifying effective appoaches in science, technology, engineering, and mathematics. [Online]. Tersedia: https://www.nap.edu/resource/13158/dbasse_071100.pdf. [28 Oktober 2019].

Widjaya, W. (2013). The use of contextual problems to support mathematical reasoning. IndoMS-JME, 4(2), 151-159. Doi: https://doi.org/10.22342/jme.4.2.413.151-159.

Yildirim, B., \& Sidekli, S. (2018). STEM application in mathematics education: the effect of STEM apllications on different dependent variables. Journal of Baltic Science Education, 17(2), 200-214. Doi: https://doi.org/10.33225/jbse/18.17.200

Yustitia, V., \& Juniarso, T. (2019). Literasi matematika mahasiswa dengan gaya belajar visual. Malih Peddas: Majalah Ilmiah Pendidikan Dasar, 9(2), 100-109. Doi: https://doi.org/10.26877/malihpeddas.v9i2.5044

Zhaahirah, W. (2014). Penerapan model pembelajaran kooperatif tipe two stay two stray pada materi luas permukaan balok. MATHEdunesa: Jurnal IImiah Pendidikan Matematika, 3(3), 252-258. 